UDC 577.151.042+547.8

\title{
Telomerase inhibition by new di- and trisubstituted acridine derivatives
}

\author{
V. V. Negrutska, I. V. Saraieva, V. G. Kostina, I. V. Alexeeva, N. A. Lysenko, I. Ya. Dubey \\ Institute of Molecular Biology and Genetics, NAS of Ukraine \\ 150, Akademika Zabolotnoho Str., Kyiv, Ukraine, 03680 \\ dubey@imbg.org.ua
}

\begin{abstract}
Aim. To study a series of new acridine derivatives containing two basic fragments able to bind to quadruplex DNA at C-4 and C-9 positions as potential telomerase inhibitors. Methods. TRAP assay was used to determine the activity of compounds in vitro. Results. A number of acridines inhibiting the enzyme at micromolar concentrations were found, with $\mathrm{IC}_{50}=2.6 \mu \mathrm{M}$ for the most active compound. Conclusions. The introduction of a highly basic N,N-dimethylaminoalkyl group at the C-9 position of the acridine core results in a strong increase of biological activity of compounds, and a 5-methyl substituent further enhances it.
\end{abstract}

Ke y w o r d s: telomerase inhibitors, acridines, quadruplex DNA, TRAP

\section{Introduction}

Telomerase is a unique reverse transcriptase synthesizing the telomeres using its own RNA component as a template and single-stranded telomeric DNA as a primer [1]. This enzyme is responsible for maintaining the telomere length and re-synthesizes the telomeric sequences partially lost upon each cellular division. Telomerase is active in a majority of tumor cells, which results in their immortalization. Increased telomerase activity was detected in 85$90 \%$ of human tumors [2]. In contrast, it is inactive in normal somatic cells. So telomerase inhibitors have a significant potential as anticancer drugs $[2,3]$.

Guanine-rich telomeric DNA sequences can fold into specific four-stranded structures called G-quadruplexes (G4) formed by the stacks of guanine quartets linked by non-canonical systems of hydrogen bonds [4-6]. Compounds able to specifically bind and stabilize G4 structures were found to inhibit telomerase and demonstrated antitumor activity. A variety of compounds, mostly containing a large heteroaromatic core, were shown to be G4-stabilizing ligands $[4,6,7]$.
A number of known telomerase inhibitors are based on acridine scaffold. Most of them contain pairs of basic substituents, e.g. at C-3 and C-6 or C-4 and $\mathrm{C}-5$ positions of the ring, and quite often an aromatic fragment at C-9 [4, 6-11]. In this work we have studied a series of novel 4,9-di and 4,5,9-trisubstituted acridines as potential telomerase inhibitors. Their biological testing was performed using the modification of classic in vitro TRAP (Telomeric Repeat Amplification Protocol) assay [12].

\section{Materials and Methods}

Acridone carboxamides 1, 2 were obtained as previously described [13]. Acridine derivatives with aliphatic basic 9-substituents were prepared from these compounds or their 5-methyl-substituted analogues (synthetic details will be reported in a separate paper).

3-([3-Cholamidopropyl]-dimethylammonium)-1propanesulfonate (CHAPS), ethyleneglycol-bis-O( $\beta$-aminoethyl)-N,N'-tetraacetic acid (EGTA) and SYBR Green I were obtained from Sigma (USA), Taq-DNA-polymerase and deoxynucleoside triphosphates from Fermentas (Lithuania).

(C) 2016 V. V. Negrutska et al.; Published by the Institute of Molecular Biology and Genetics, NAS of Ukraine on behalf of Biopolymers and Cell. This is an Open Access article distributed under the terms of the Creative Commons Attribution License (http://creativecommons.org/licenses/by/4.0/), which permits unrestricted reuse, distribution, and reproduction in any medium, provided the original work is properly cited 
Telomerase was extracted from exponentially growing MCF-7 tumor cells by lysing in a CHAPS/ EGTA-based buffer [14].

TRAP analysis was performed according to TRAPeze protocol [TRAPeze ${ }^{\circledR}$ Telomerase Detection Kit. Chemicon International, Temecula, CA, USA, 2005. 39 p.] with deoxyoligonucleotide primers 5'-GTGCCCTTACCCTTACCCTTACCCTAA (CXext) [15] and 5'-AATCCGTCGAGCAGAGTT (TS) from Eurogentec (Belgium). Inhibitors were tested in a concentration range from 40 to $0.625 \mu \mathrm{M}$ using a serial 2-fold dilution. After the telomerase extension reaction the tested compounds were removed from the mixture by phenol/chloroform extraction followed by ethanol precipitation. PCRamplified DNA products were analyzed by gel electrophoresis. $20 \mu \mathrm{L}$ sample was mixed with $2 \mu \mathrm{L}$ of loading buffer (5x TBE buffer, $20 \%$ sucrose, $0.2 \%$ bromophenol blue) and loaded onto a standard $12 \%$ non-denaturing polyacrylamide gel (19:1) prepared in $0.5 \mathrm{x}$ TBE. Electrophoresis was run for $0.5 \mathrm{~h}$ at $160 \mathrm{~V}$ and then for $0.5 \mathrm{~h}$ at $300 \mathrm{~V}$. Gel was stained with 1x SYBR Green I for $30 \mathrm{~min}$ at room temperature. DNA bands were visualized on a ChemiDoc imager (Bio-Rad, USA), and images were processed

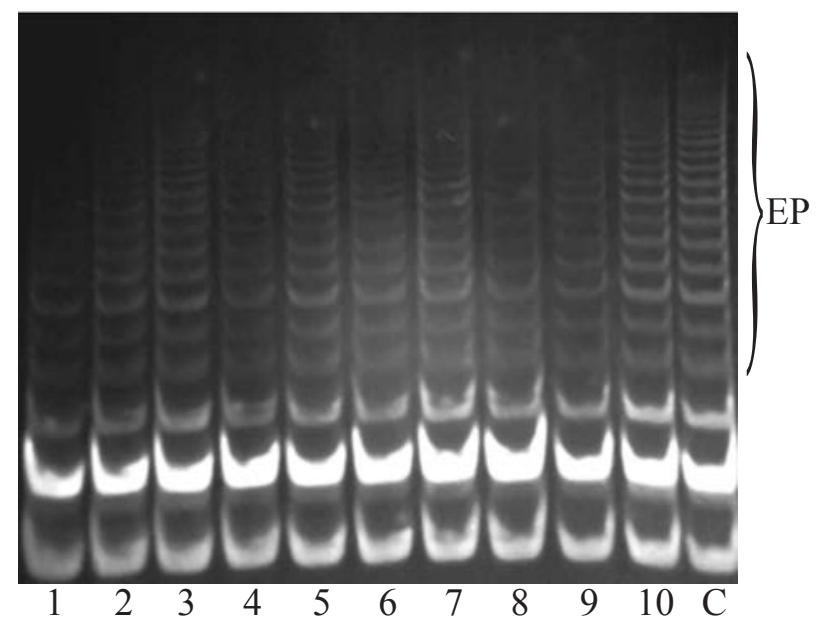

Fig. 1. TRAP analysis of the effect of acridines on telomerase activity. Lanes 1-3 - compound 5 (20, 10 and $5 \mu \mathrm{M})$; lanes 4-5 compound 6 (10 and $5 \mu \mathrm{M})$; lanes 6-7 - compound 8 (2.5 and $1.25 \mu \mathrm{M})$; lanes $8-10$ - compound $7(2.5,1.25$ and $0.625 \mu \mathrm{M})$; $\mathrm{C}$ - control reaction. $\mathrm{EP}$ - elongation products. with TotallLab v2.01 software (Nonlinear Dynamics, UK).

Inhibition activity was determined by comparing the amount of DNA produced in the test assay with that in a control reaction with no inhibitor added. For quantitative analysis, optical densities of the sets of DNA product bands on corresponding lanes of the gel were integrated. $\mathrm{IC}_{50}$ values (compound concentrations required for achieving $50 \%$ inhibition of enzymatic activity) were obtained from the concentration-activity plots. At least three independent experiments were performed for each compound.

\section{Results and Discussion}

We have recently found that acridone derivatives containing pyridyl groups at 4-carboxamide fragment inhibit telomerase at $100 \mu \mathrm{M}$ concentration. Molecular modeling suggested the introduction of additional phosphate-binding group in these compounds to improve their G4 binding and thus inhibition activity [16]. A series of new acridine derivatives with two aliphatic and aromatic basic fragments were synthesized. The structures of potential inhibitors (Table) were designed taking into account that strongly basic group like N,N-dimethylaminoalkyl introduced at C-9 position is easily protonated in water and thus could interact with G4 phosphate anions enhancing the ligand binding. In addition to phosphate binding, the basic pyridyl function at 4-carboxamide was expected to form hydrophobic bonds with G4 DNA bases further increasing the ligand affinity.

The level of telomerase inhibition was determined in TRAP assay. In this 2-step method [12], telomerase enzymatic reaction is followed by PCR amplification of its DNA products and analysis of the resulting reaction mixture by gel electrophoresis. Tumor cell lysate is used as the source of telomerase. We have employed TRAPeze protocol from Chemicon [TRAPeze ${ }^{\circledR}$ Telomerase Detection Kit. Chemicon International, Temecula, CA, USA, 2005. 39 p.], a well-established modification of the original method [12]. The inhibitors were removed from the reaction mixture before the PCR step to exclude their possi- 
Table. In vitro telomerase inhibition activity of acridone and acridine derivatives in TRAP assay.

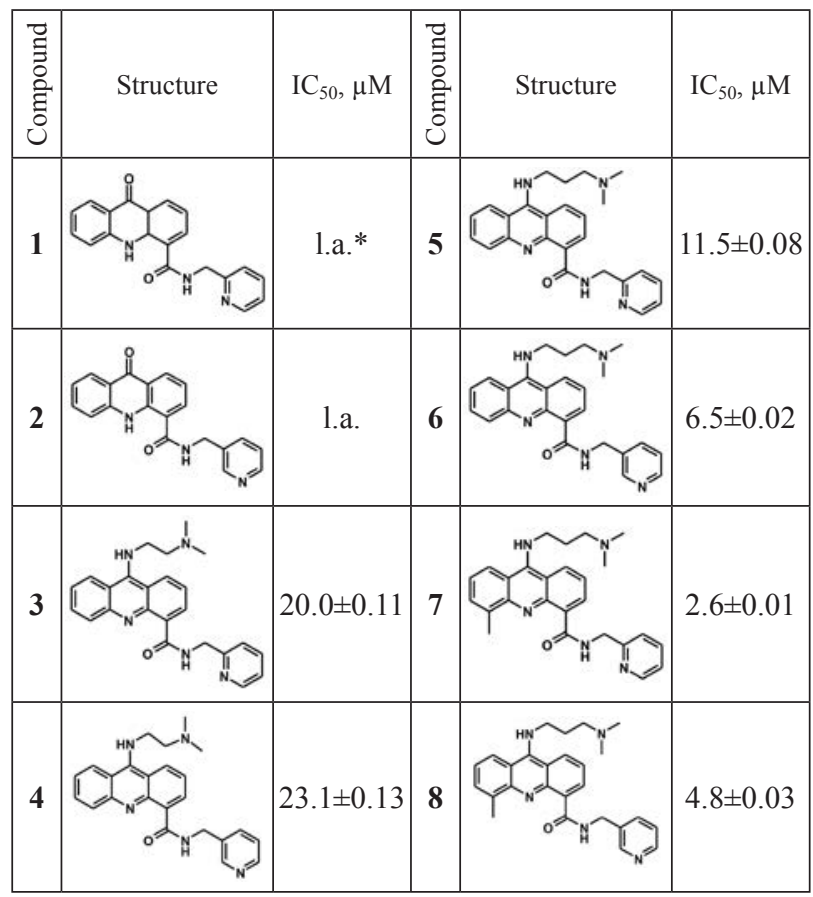

* low activity $\left(\mathrm{IC}_{50}>40 \mu \mathrm{M}\right)$

ble effect on Taq-DNA-polymerase. Alternative reverse PCR primer CXext developed to minimize analysis artifacts [15] was used instead of the standard CX.

The compounds were tested in a concentration range $40-0.625 \mu \mathrm{M}$ (Fig. 1). The activity plots built by calculating the yield of enzymatic reaction products as a function of drug concentration allowed determining the $\mathrm{IC}_{50}$ values of inhibitors (Table).

The test results confirmed the idea of structure design to be correct. 9-Acridone derivatives 1-2 with $o$ - and $m$-pyridyl fragments were relatively inactive as telomerase inhibitors. However, the activity of all 9-substituted analogues bearing strongly basic functions sharply increased. The inhibition data indicated a higher activity of the compounds with N,N-dimethylaminopropyl residue $(\mathbf{5}, \mathbf{6})$ as compared to their analogues containing a shorter $\mathrm{Me}_{2} \mathrm{NCH}_{2} \mathrm{CH}_{2}$ group $(3,4)$. As expected, electron-donating 5-methyl substituent significantly enhanced the biological activity (compare the $\mathrm{IC}_{50}$ values of compounds 7 and 5, 8 and 6), perhaps due to increasing the electronic density on acridine core which resulted in its more efficient $\pi-\pi$ stacking with G4.

\section{Conclusions}

4,9- and 4,5,9-substiuted acridines containing two basic DNA-binding moieties efficiently inhibit telomerase in vitro at low micromolar concentrations. Trisubstituted derivative 7 with $\mathrm{IC}_{50}=2.6 \mu \mathrm{M}$ is the most active inhibitor. The key structural feature determining the activity of compounds is a presence of highly basic N,N-dimethylaminoalkyl group at C-9 position. Further optimization would allow the development of more potent acridine-based telomerase inhibitors.

\section{Acknowledgement}

Authors are grateful to Dr. A. Khoruzhenko for providing the culture of MCF-7 cells.

\section{Funding}

This research was in part supported by the NAS of Ukraine program "Molecular and Cellular Biotechnologies for Medicine, Industry and Agriculture" (grant 43/16).

\section{REFERENCES}

1. Cong YS, Wright WE, Shay JW. Human telomerase and its regulation. Microbiol Mol Biol Rev. 2002; 66(3):407-25.

2. Ruden $M$, Puri $N$. Novel anticancer therapeutics targeting telomerase. Cancer Treat Rev. 2013; 39(5):444-56.

3. Sekaran V, Soares J, Jarstfer MB. Telomere maintenance as a target for drug discovery. J Med Chem. 2014; 57(3):521-38.

4. $X u \quad Y$. Chemistry in human telomere biology: structure, function and targeting of telomere DNA/RNA. Chem Soc Rev. 2011; 40:2719-40.

5. Neidle S. Quadruplex nucleic acids as novel therapeutic targets. J Med Chem. 2016; 9(13):5987-6011.

6. Maji B, Bhattacharya S. Advances in the molecular design of potential anticancer agents via targeting of human telomeric DNA. Chem Commun. 2014; 50(49):6422-38.

7. Monchaud D, Teulade-Fichou M.-P. A hitchhiker's guide to G-quadruplex ligands. Org Biomol Chem. 2008; 6(4): 627-36. 
8. Cuenca F, Moore MJB, Johnson K, Guyen B, De Cian A, Neidle $S$. Design, synthesis and evaluation of 4,5-di-substituted acridone ligands with high G-quadruplex affinity and selectivity, together with low toxicity to normal cells. Bioorg Med Chem Lett. 2009; 19(17):5109-13.

9. Sparapani S, Haider SM, Doria F, Gunaratnam M, Neidle $S$. Rational design of acridine-based ligands with selectivity for human telomeric quadruplexes. J Am Chem Soc. 2010; 132(35):12263-72.

10. Ungvarsky J, Plsikova J, Janovec L, Koval J, Mikes J, Mikesová L, Harvanova D, Fedorocko P, Kristian P, Kasparkova J, Brabec V, Vojtickova M, Sabolova D, Stramova Z, Rosocha J, Imrich J, Kozurkova M. Novel trisubstituted acridines as human telomeric quadruplex binding ligands. Bioorg Chem. 2014; 57:13-29.

11. Gao C, Zhang W, He S, Li S, Liu F, Jiang Y. Synthesis and antiproliferative activity of 2,7-diamino 10-(3,5-dimethoxy) benzyl-9 $(10 \mathrm{H})$-acridone derivatives as potent telomeric Gquadruplex DNA ligands. Bioorg Chem. 2015; 60:30-6.

12. Kim NW, Piatyszek MA, Prowse KR, Harley CB, West MD, Ho PL, Coviello GM, Wright WE, Weinrich SL, Shay JW. Specific association of human telomerase activity with immortal cells and cancer. Science. 1994; 266(5193):2011-15.

13. Kostina VG, Alexeeva IV, Lysenko NA, Negrutska VV, Dubey IYa. Synthesis and biological evaluation of new derivatives of tricyclic heteroaromatic carboxamides as potential topoisomerase I inhibitors. Ukr Bioorg Acta. 2016; 14(1):3-8.

14. Burger AM. Standard TRAP assay. In: Telomeres and Telomerase: Methods and Protocols. Eds. Double JA, Thompson MJ. Humana Press: Totowa, NJ, USA, 2002: 109-24.

15. Krupp G, Kühne K, Tamm S, Klapper W, Heidorn K, Rott A, Parwaresch $R$. Molecular basis of artifacts in the detection of telomerase activity and a modified primer for a more robust 'TRAP' assay. Nucleic Acids Res. 1997; 25(4):919-21.

16. Negrutska VV, Dubey LV, Ilchenko MM, Dubey IYa. Design and study of telomerase inhibitors based on G-quadruplex ligands. Biopolym Cell. 2013; 29(3):169-76.

\section{Інгібування теломерази новими ди- та тризаміщеними похідними акридину}

В. В. Негруцька, І. В. Сараєва, В. Г. Костіна, I. В. Алексєєва, Н. А. Лисенко, І. Я. Дубей

Мета. Дослідити серію нових похідних акридину, що містять у положеннях C-4 і C-9 два основні фрагменти, здатні зв'язуватися $з$ квадруплексною ДНК, як потенційних інгібіторів теломерази. Методи. Для визначення активності сполук in vitro використано метод ТRAР. Результати. Виявлено ряд акридинів, що інгібують фермент у низьких мікромолярних концентраціях, для найактивнішого з яких $\mathrm{IC}_{50}=2.6$ мкМ. Висновки. При введенні високоосновної N,N-диметиламіноалкільної групи в положення C-9 акридинового ядра біологічна активність сполук різко зростає, а 5-метильний замісник додатково збільшує іiі.

К л юч о в і с л о в а: інгібітори теломерази, акридини, квадруплексна ДНК, ТRАР

\section{Ингибирование теломеразы новыми ди- и тризамещенными производными акридина}

В. В. Негруцкая, И. В. Сараева, В. Г. Костина, И. В. Алексеева, Н. А. Лысенко, И. Я. Дубей

Цель. Изучить серию новых производных акридина, содержащих в положениях C-4 и C-9 два основных фрагмента, способных связываться с квадруплексной ДНК, как потенциальных ингибиторов теломеразы. Методы. Для определения активности веществ in vitro использован метод TRAP. Результаты. Обнаружен ряд акридинов, ингибирующих фермент в низких микромолярных концентрациях, для самого активного из котоpых $\mathrm{IC}_{50}=2.6$ мкМ. Выводы. При введении высокоосновной $\mathrm{N}, \mathrm{N}$-диметиламиноадкильной группы в положении C-9 акридинового ядра биологическая активность соединений резко возрастает, а 5-метильный заместитель дополнительно увеличивает ее.

Ключе в ы е сл в а: ингибиторы теломеразы, акридины, квадруплексная ДНК, TRAP

Received 10.10.2016 